\title{
KINETICS OF THE ANODIC REACTION OF MOLTEN NITRITES ON PLATINUM*
}

\author{
A. J. Calandra and A. J. Arvía \\ Instituto Superior de Investigaciones, Facultad de Quimica y Farmacia, \\ Universidad Nacional de La Plata, La Plata, Argentina
}

\begin{abstract}
The kinetics of the anodic reaction occurring on platinum electrodes when molten nitrites are electrolysed has been studied from 240 to $340^{\circ} \mathrm{C}$. The following electrolytes were used (i) molten sodium nitrite (ii) mixtures of molten sodium and potassium nitrites (iii) solutions of nitrites in the sodium-nitrate-potassium-nitrate eutectic, covering the concentration range from 10 to $10^{-1} \mathrm{M}$. The overall anodic reaction is
\end{abstract}

$$
\mathrm{NO}_{2}^{-} \rightarrow \mathrm{NO}_{2}+\mathrm{e} .
$$

Current/voltages curves, and decay and build-up of electrode overpotential were measured and the results analysed in the usual way. After the interruption of the electrolysis current a steady residual potential was established on the working electrode.

Current/voltage curves fit a Tafel plot in two regions of current density. At lower current density the slope approaches $2 \cdot 3(R T / F)$, whereas at higher ones it becomes $2 \cdot 3(R T / 2 F)$. Two slopes are also obtained from the logarithmic plot of overpotential decay for the pure nitrites at high current density; the results are satisfactorily coincident with those already mentioned. The transition from the higher to the lower Tafel line occurs at an overpotiential of about $300 \mathrm{mV}$. From the decay curves the apparent electrode capacitance and its dependence on potential within a certain range of the latter was calculated.

The interpretation of results is based upon a simple reaction scheme involving a fast discharge of nitrite ion followed by two alternative reactions for the intermediate formed in the initial discharge, finally yielding nitrogen dioxide. Possibilities related to a low or an intermediate degree of coverage of the electrode surface are discussed.

Résumé-La cinétique de la réaction anodique qui a lieu sur les électrodes de platine au cours de l'électrolyse de nitrites fondus, a été étudiée entre 240 et $340^{\circ} \mathrm{C}$. Les électrolytes suivants furent employés (i) nitrite de soude fondu (ii) des mélanges de nitrite de soude et nitrite de potasse (iii) des solutions de nitrites dans l'eutectique nitrate-de-soude-nitrate-de-potasse, à des concentrations allant de 10 à $10^{-1} \mathrm{M}$. La réaction anodique totale est

$$
\mathrm{NO}_{2}^{-} \rightarrow \mathrm{NO}_{2}+\text { e. }
$$

Les courbes de polarisation et de décroissance ou d'accroissement de la surtension ont été établies et les résultats analysés de la manière habituelle. Après l'interruption du courant d'électrolyse, un potentiel résiduel constant fut constaté sur Yélectrode de travail.

Les courbes de polarisation concordent avec la ligne de Tafel sur deux sections de densité de courant. A basse densité de courant l'inclinaison est à peu près $2 \cdot 3(R T / F)$ tandis qu'à densité plus elevée elle est 2.3 $(R T / 2 F)$. Deux pentes sont obtenues également du graphique logarithmique de la decroissance de la surtension pour les nitrites purs, à densité de courant élevée. Elles sont en bonne concordance avec celles mentionnées avant. Le transition de la ligne de Tafel plus élevée à la ligne plus basse se produit à un surtension d'environ $300 \mathrm{mV}$.

Des courbes de décroissance on a déduit la capacitance apparente d'électrode et sa dépendance du potentiel dans certaines limites de celui-ci.

L'interprétation des résultats se base sur un simple schéma de réaction comportant une décharge rapide d'un ion de nitrite suivie par deux réactions alternatives pour l'intermédiaire formé pendent la décharge initiale et produisant finalement du dioxide de nitrogène. On discute les possibilités qui apparaissent dans le cas d'un degré de couverture bas ou intermédiaire de la surface d'electrode.

- Manuscript received 10 December 1965. 
Zusammenfassung-Die Kinetik der anodischen Reaktion welche an Platinelektroden stattfindet, wenn geschmolzene Nitrite elektrolysiert werden, wurde im Temperaturbereich von 240 bis $340^{\circ} \mathrm{C}$ studiert Als Elektroden wurden benutzt (i) geschmolzenes Natriumnitrit (ii) Mischungen von geschmolzenem Natrium- und Kaliumnitrit (iii) Nitritlösungen im Eutektikum Natriumnitrat-Kaliumnitrat mit Konzentrationen von 10 bis $10^{-1} \mathrm{M}$. Die gesamte anodische Reaktion ist

$$
\mathrm{NO}_{2}^{-} \rightarrow \mathrm{NO},+e \text {. }
$$

Strom-Spannungskurven sowie Abschalt- und Einschaltkurven der Elektrodenüberspannung wurden gemessen und die Ergebnisse wie üblich gedeutet. Nach Ausschaltung des Elektrolysestromes wurde ein konstantes Ruhepotential an der Arbeitselektrode beobachtet.

Die Strom-Spannungskurven stimmen mit einem Tafeldiagramm in zwei Stromdichtebereichen überein. Bei niedriger Stromdichte ist die Steigung annähernd 2,3 $(R T / F)$, während sie bei höheren Stromdichten 2,3 $(R T / 2 F)$ wird. Zwei steigung werden auch beim logarithmischen Diagramm des Polarisations zerfalls für reine Nitrite bei hoher Stromdichte ermittelt; sie stimmen befriedigend mit den schon erwähnten tiberein. Der Übergang von der höheren zur niedrigeren Tafelsteigung findet bei einer Uberspannung von ungefähr $300 \mathrm{mV}$ statt.

Mittels der Zerfallskurven wurde die scheinbare Elektrodenkapazitat und ihre Abhängigkeit vom Potentials innerhalb eines gewissen Bereiches des letzteren berechnet.

Die Deutung der Ergebnisse fusst auf einem einfachen Reaktionsschema, das die schnelle Entladung eines Nitritions, gefolgt von zwei möglichen Reaktionen für das primar gebildete Zwischenprodukt unter Bildung von Stickstoffdioxyd als Endprodukt postuliert. Die aus einem niedrigen oder mittleren Bedeckungsgrad der Elektrodenoberfläche sich ergebenden Möglichkeiten werden diskutiert.

\section{INTRODUCTION}

Previous publications ${ }^{1.2}$ on the electrochemical behaviour of molten nitrites have dealt with salt dissolved in the eutectic $\mathrm{KNO}_{3}-\mathrm{NaNO}_{3}$, and were mainly concerned with polarographic studies. Very recently ${ }^{3}$ this was also the subject of an extensive study which confirmed that the oxidation of the nitrite ion in the molten state yields only nitrogen dioxide according to the total reaction,

$$
\mathrm{NO}_{2}^{-}=\mathrm{NO}_{2}+\mathrm{e} \text {. }
$$

The behaviour of an electrolyte containing only pure molten nitrite was also recently reported. This preliminary information encouraged us to attempt the detailed study of the whole anodic reaction, comprising both its thermodynamics and its kinetics.

The present study was further induced by the results obtained for the thermodynamics and kinetics related to the electrolysis of molten nitrates, which have already been published. ${ }^{5.6}$ From these previous experiments it was concluded that a great deal of information to some extent related to it could also be obtained from the electrolysis of molten nitrites. Thus in the electrolysis of pure molten nitrites, if a fast enough electron-transfer process exists, a reversible electrode in the molten state, involving nitrite ions, should be observed.

Furthermore, in the electrolysis of molten nitrites a smaller number of intermediates than in the case of molten nitrates should be expected and consequently the kinetics of the reaction may well follow a relatively simple reaction scheme.

\section{Electrolysis cell}

\section{EXPERIMENTAL TECHNIQUE}

Most of the features of the electrolysis cell are given in a previous publication. ${ }^{7}$ However, a few details particularly related to the electrodes deserve further description. Three electrodes were accommodated in the cell containing about $150 \mathrm{~cm}^{3}$ of the molten electrolyte. The cathode was a stainless steel wire of about $3 \mathrm{~cm}^{2}$ which was placed in a glass compartment having a sintered glass disk of small diameter at the 
bottom to avoid any product originating in the cathodic section mixing with the electrolyte at the working electrode.

The anode was made from platinum wires of different diameters and the geometrical area of the electrodes was varied from 1 to $4 \mathrm{~cm}^{2}$ or thereabouts. The working electrodes were mounted in glass tubes with wide open ends to introduce the capillary tip of the reference electrode exactly as far as required. The gas composition in the anodic compartment was also controlled by a suitable arrangement of inlet and outlet tubes.

Two different reference electrodes were used. Initially a silver/silver-nitrate reference electrode in sodium-nitrate-potassium-nitrate eutectic was tried. Although it gave satisfactory results during the first hours of the experiments, later on some chemical decomposition was observed in the electrode where some sodium nitrite had come into contact with the nitrate mixture.

The best reproducible results were obtained with a nitrite reference electrode consisting of a platinum wire dipped into molten sodium nitrite and built into a special compartment. The whole electrode was saturated with nitrogen dioxide formed in situ by previous electrolysis. The potential attained by this electrode was very stable for a long time. A further advantage of using the second reference electrode was that a symmetrical electrochemical system was obtained when the pure molten salt was electrolysed and consequently no liquid junction was involved.

\section{Electrolytes}

Three different electrolytes were used: (i) pure sodium nitrite (ii) equimolar mixtures of sodium nitrite and potassium nitrite and (iii) different solutions of sodium nitrite in the eutectic of sodium nitrate and potassium nitrate (1:1). A.R. quality Mallinckrodt chemicals were chosen. They were further purified before use and the electrolytes prepared by mixing, evacuation and filtration, as indicated elsewhere. ${ }^{6}$ The molten electrolytes, when in the cell, were saturated with purified nitrogen before electrolysing.

\section{Working conditions}

The electrochemical reaction was studied between 240 and $340^{\circ} \mathrm{C}$. The experimental information was obtained by measuring conventional current/voltage curves and potential/time dependence as the electrolysis current was switched on and off. The former were obtained with current ranging from a few $\mu \mathrm{A}$ to about $300 \mathrm{~mA}$ while the latter were recorded during periods from $10 \mu$ s to about 30 min. Build-up curves were obtained with a galvanostatic device. The measuring circuitry was essentially the same as that previously described. ${ }^{6}$

\section{RESULTS}

\section{Current/potential relationship}

Typical current/potential curves are shown in Figs. 1-3 for experiments using pure nitrites and nitrites dissolved in the nitrate mixture. The current density was calculated from the apparent electrode area. If $E_{i}$ is the potential of the working electrode measured against the reference electrode, for the current density $i$, and $E_{0}$ its potential when no current flows through the cell, the overpotential $\eta$ is

$$
\eta=E_{i}-E_{0} \text {. }
$$




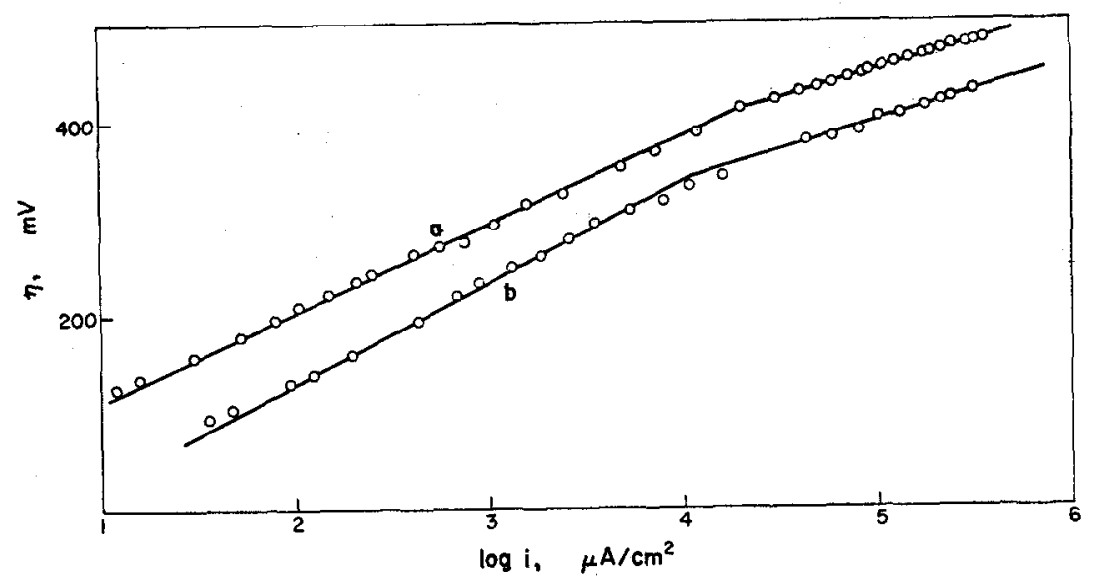

Frg. 1. Tafel plots at different temperatures.

a, $244^{\circ} \mathrm{C}$

b, $310^{\circ} \mathrm{C}$

$\mathrm{KNO}_{2}-\mathrm{NaNO}_{\mathbf{z}}$

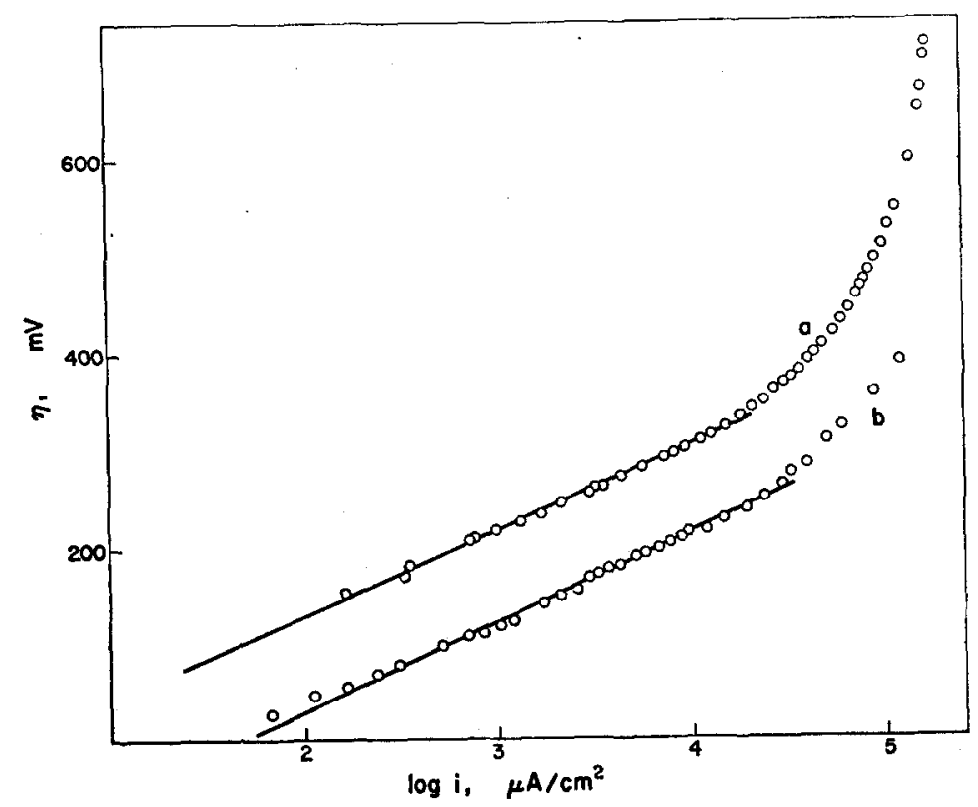

FIG. 2. Tafel plots at different sodium nitrite concentrations.

a, $282^{\circ} \mathrm{C} 1.08 \mathrm{M} \mathrm{NaNO}_{2}$

b, $279^{\circ} \mathrm{C} 10.8 \mathrm{M} \mathrm{NaNO}_{2}$ 
$E_{0}$ was nil when a nitrite electrode was used as reference. The correction for pseudooverpotential due to ohmic drop, important at high current densities, was measured in the oscilloscope trace, where it appeared as an instantaneous potential drop, linearly related to current density. It was reduced in the set-up used in the present work to about $0 \cdot 1 \Omega$.

Current/potential curves cover the range 20 to $5 \times 10^{5} \mu \mathrm{A} / \mathrm{cm}^{2}$ and the experimental data obtained with the pure nitrite melt can be grouped in two clearly defined regions each corresponding to a particular Tafel line.

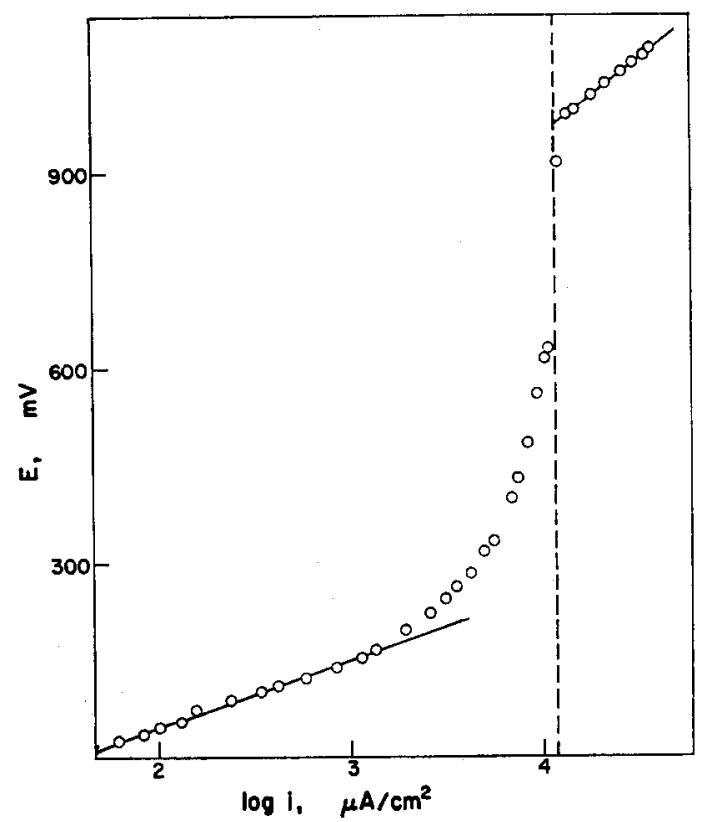

Fig. 3. Tafel plot for the diluted salt. Potential region of nitrate discharge is shown.

$$
\begin{aligned}
& 285^{\circ} \mathrm{C} \\
& 0 \cdot 11 \mathrm{M} \mathrm{NaNO} \\
& \mathrm{KNO}_{3}-\mathrm{NaNO}_{3} \\
& \mathrm{Ag} / \mathrm{Ag}^{+} \text {reference electrode }
\end{aligned}
$$

The results of the first region, which comprises $\log i\left(\mu \mathrm{A} / \mathrm{cm}^{2}\right)$ values between 1 and $4 \cdot 5$, fall on a straight line having an average slope of $2 \cdot 3(R T / F)$. The results for the second region, at higher current densities, fall on a straight line having on the average a slope of $2 \cdot 3(R T / 2 F)$. Between the two Tafel lines shown in the curve there is clearly a transition region corresponding to an overpotential of $300 \pm 50 \mathrm{mV}$ at $277^{\circ} \mathrm{C}$.

The extrapolation of the Tafel lines to zero overpotential yields respectively two values of the apparent exchange current densities, which are indicated in Table 1, where the $b$ 's are the Tafel slopes and the $i_{0}$ 's are the apparent exchange current densities; the subscripts ${ }_{1}$ and ${ }_{2}$ refer to the higher and lower Tafel slopes respectively.

When current/voltage curves obtained with the diluted nitrites are considered at high current densities, a limiting current is observed, which for the more dilute systems is proportional to the nitrite concentration. Due to the interference of the convective-diffusion process, the region of lower Tafel slope, previously reported, is 
not observed now. If the overpotential is further increased beyond the limiting current region the discharge of nitrate ions starts and their own Tafel slope, 2.3 $(2 R T / F)$, earlier reported, ${ }^{6}$ becomes evident, as shown in Fig. 3. Values of Tafel slopes for the diluted nitrite and the current density corresponding to an overvoltage of $200 \mathrm{mV}$ are assembled in Table 2, where the concentration of nitrate in the melt is also indicated.

TABLE 1

\begin{tabular}{|c|c|c|c|c|c|c|}
\hline$\underset{{ }^{\circ} \mathrm{C}}{\text { Temp. }}$ & $\begin{array}{c}b_{1} \\
\mathrm{mV}\end{array}$ & $\begin{array}{c}b_{\mathbf{q}} \\
\mathrm{mV}\end{array}$ & $\begin{array}{c}2 \cdot 303(R T / F) \\
\mathrm{mV}\end{array}$ & $\begin{array}{c}\left(i_{0}\right)_{1} \times 10^{6} \\
\mathbf{A} / \mathrm{cm}^{2}\end{array}$ & $\begin{array}{c}\left(i_{0}\right)_{2} \times 10^{9} \\
\mathrm{~A} / \mathrm{cm}^{2}\end{array}$ & Electrolyte \\
\hline 310 & $114 \pm 10$ & $58 \pm 5$ & $115 \cdot 7$ & $7 \cdot 3$ & $21 \cdot 7$ & $\mathrm{NaNO}_{2}$ \\
\hline 310 & 106 & $\perp$ & 115.7 & 5.4 & - & NaNO,-KNO, \\
\hline 310 & 106 & 60 & $115 \cdot 7$ & $6 \cdot 4$ & $16 \cdot 0$ & $\mathrm{NaNO}$-KNO, \\
\hline 306 & 116 & - & 114.9 & 5.9 & - & $\mathrm{NaNO}_{2}-\mathrm{KNO}_{2}$ \\
\hline 303 & 110 & 59 & $114 \cdot 3$ & $4 \cdot 3$ & $10 \cdot 7$ & $\mathrm{NaNO}_{2}-\mathrm{KNO}$ \\
\hline 298 & 116 & - & $113 \cdot 3$ & $2 \cdot 7$ & - & $\mathrm{NaNO}_{2}$ \\
\hline 277 & 104 & 57 & $109 \cdot 2$ & 1.8 & 1.9 & $\mathrm{NaNO}_{2}-\mathrm{KNO}_{2}$ \\
\hline 277 & 107 & 57 & $109 \cdot 2$ & 1.5 & $1 \cdot 5$ & $\mathrm{NaNO}_{2}-\mathrm{KNO}_{2}$ \\
\hline 244 & 92 & 53 & 102.6 & 0.54 & $0 \cdot 37$ & $\mathrm{NaNO}_{2}-\mathrm{KNO}_{2}$ \\
\hline
\end{tabular}

The foregoing results show that the current density, at constant temperature and overpotential, decreases with the nitrite concentration; to a first approximation the relationship is linear.

The increase of temperature decreases the overpotential at a fixed current density. Table 1 shows this effect as well as current/voltages curves.

The overpotential related to the transition from the slope $2 \cdot 3(R T / F)$ to $2 \cdot 3(R T / 2 F)$ decreases as the temperature increases; when the electrochemical reaction is carried out at $345^{\circ} \mathrm{C}$, only a slope approaching $2 \cdot 3(R T / 2 F)$ is observed, as shown in Fig. 4 -the higher slope and the transition overpotential are not well defined.

TABLE 2

\begin{tabular}{ccccc}
\hline $\begin{array}{c}\text { Temp. } \\
{ }^{\circ} \mathrm{C}\end{array}$ & $\begin{array}{c}b_{1} \\
\mathrm{mV}\end{array}$ & $\begin{array}{c}2 \cdot 303(R T / F) \\
\mathrm{mV}\end{array}$ & $\begin{array}{c}(i)_{\eta=200 \mathrm{mV}} \times 10^{3} \\
\mathrm{~A} / \mathrm{cm}^{2}\end{array}$ & $\begin{array}{c}\mathrm{NaNO}_{2} \\
\mathrm{M}\end{array}$ \\
\hline 282 & $104 \pm 10$ & 110.2 & 6.51 & 1.08 \\
282 & 100 & 110.2 & 7.08 & 1.08 \\
279 & 96 & 109.6 & 0.71 & 10.8 \\
279 & 93 & 109.6 & 0.82 & 10.8 \\
\hline
\end{tabular}

The effect of temperature on the exchange current density is clearly observed. It increases as temperature increases, following an Arrhenius equation. Thus, the following experimental activation energies are obtained: $\left(E_{1}\right)_{\exp }=20 \pm 3 \mathrm{Kcal} / \mathrm{mole}$ and $\left(E_{2}\right)_{\exp }=36 \pm 6 \mathrm{Kcal} / \mathrm{mole}$.

\section{Decay of overvoltage}

Typical decay curves obtained at different sweeping rates by oscilloscope and recorder are plotted in Fig. 5. For molten nitrites the overpotential decays logarithmically with time, in both regions, except when it is approaching the reversible potential, when it is plotted according to

$$
\eta_{t}=A-b_{d} \log \left(t+t^{\prime}\right)
$$




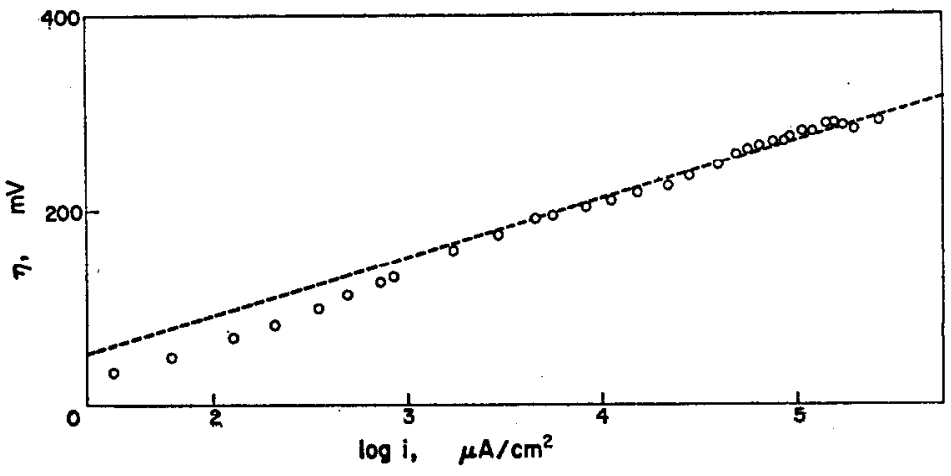

FIG. 4. Tafel plot at the highest temperature used in the experiments.

$$
345^{\circ} \mathrm{C}
$$

$\mathrm{KNO}_{2}-\mathrm{NaNO}_{2}$

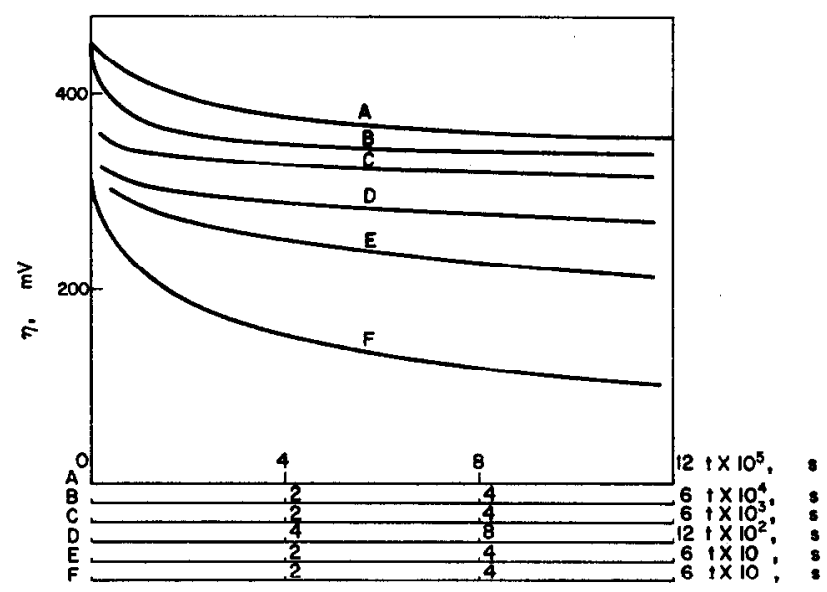

Fig. 5. Decay of anodic overpotential. A, B, C, D, E and F are records obtained at different rates.

$276^{\circ} \mathrm{C}$

$32.4 \mathrm{~mA} / \mathrm{cm}^{2}$

$\mathrm{NaNO}_{2}-\mathrm{KNO}_{2}$

as shown in Figs. 6 and 7. In (2), $\eta_{t}$ is the overpotential at the time $t$ elapsed since the interruption of the electrolysis; $t^{\prime}$ is a constant evaluated from the decay curves of a previous plot of $\eta$ versus $\log t$, as early described ${ }^{6} ; A$ and $b_{d}$ are parameters characteristic of the electrode system studied, and $b_{d}$ is equivalent to the Tafel slope, under certain limiting conditions.

As the decay curves plotted according to (2) present two slopes, two values of $b_{d}$ and $t^{\prime}$ are in principle possible. It is remarkable that the decay curves obtained within the range of higher current densities are coincident.

The first linear region, at higher overpotentials, extends up to about $100 \mathrm{~ms}$ and its slope is close to $2 \cdot 3(R T / 2 F)$. The second linear region is observed beyond $100 \mathrm{~ms}$ and approaches $2 \cdot 3(R T / F)$. The transition from the former to the latter portion occurs at $320 \pm 50 \mathrm{mV}$, at $270^{\circ} \mathrm{C}$. 


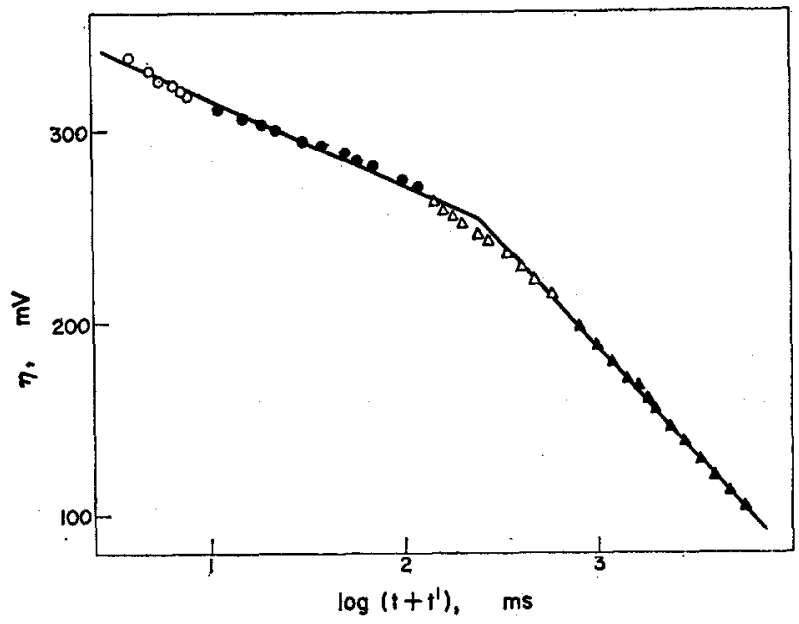

FIG. 6. Decay of overpotential according to (2).

$$
276^{\circ} \mathrm{C}
$$

$32.4 \mathrm{~mA} / \mathrm{cm}^{2}$

$\mathrm{KNO}_{2}-\mathrm{NaNO}_{2}$

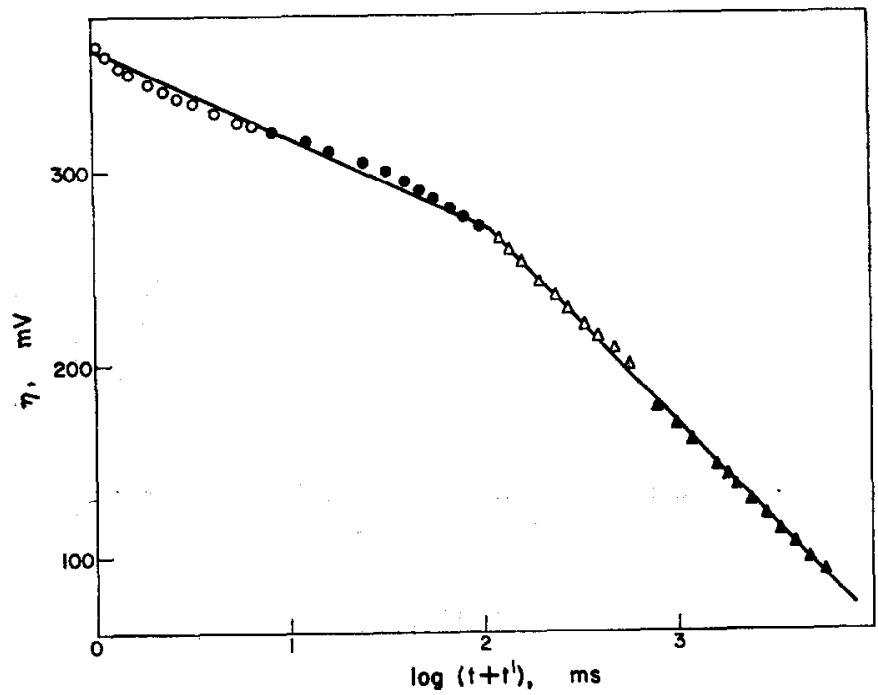

Frg. 7. Decay of overpotential according to (2).

$$
\begin{aligned}
& 276^{\circ} \mathrm{C} \\
& 96.2 \mathrm{~mA} / \mathrm{cm}^{2} \\
& \mathrm{KNO},-\mathrm{NaNO}_{2}
\end{aligned}
$$

The electrode capacitance $C$, at the interruption of the current, is obtained from $t^{\prime}$ since $C=i t^{\prime} \mid b_{d}{ }^{\prime} . \quad b_{d}{ }^{\prime}$ is the slope of the decay curves divided by $2 \cdot 3$.

The apparent exchange current density was calculated also from

$$
i_{0}=\frac{C b_{d}^{\prime}}{t} \exp \left(\frac{\eta_{t}}{b_{d}^{\prime}}\right) \text {. }
$$

Values of $i$, the current density prior to the interruption, $\left(b_{d}\right)_{1}, t_{1}{ }^{\prime}, C,\left(i_{0}\right)_{1}$ and $\eta_{\text {, }}$ the overvoltage at current density $i$, are assembled in Table 3. Values of $t_{2}{ }^{\prime}$ and $\left(i_{0}\right)_{2}$ 
are not included because of the large error involved in their calculation, although their order of magnitude as obtained from the figures is reasonable.

The effect of temperature on $b_{d}$ and $t^{\prime}$ are shown in Table 3. Results obtained from decay curves coincide with those already mentioned for the current/potential curves.

TABLe 3. Electrolyte: $\mathrm{NaNO}_{2}-\mathrm{KNO}_{2}$

\begin{tabular}{|c|c|c|c|c|c|c|c|}
\hline$\underset{{ }^{\circ} \mathrm{C}}{\text { Temp. }}$ & $\stackrel{i}{\mathrm{~mA} / \mathrm{cm}^{2}}$ & $\begin{array}{l}\left(b_{d}\right)_{1} \\
\mathrm{mV}\end{array}$ & $\begin{array}{c}2 \cdot 303(R T / F) \\
\mathrm{mV}\end{array}$ & $\begin{array}{l}t_{1}^{\prime} \\
\mathrm{ms}\end{array}$ & $\underset{\mu \mathrm{F} / \mathrm{cm}^{2}}{C}$ & $\begin{array}{c}\left(i_{0}\right)_{1} \times 10^{6} \\
\mathrm{~A} / \mathrm{cm}^{2}\end{array}$ & $\stackrel{\eta}{m V}$ \\
\hline 303 & $16 \cdot 1$ & $102 \pm 5$ & $114 \cdot 3$ & $4 \cdot 66$ & $1287 \pm 100$ & 1.5 & $395 \cdot 0$ \\
\hline 292 & 26.9 & 110 & $112 \cdot 2$ & $2 \cdot 50$ & 1406 & $3 \cdot 4$ & $430 \cdot 0$ \\
\hline 276 & $152 \cdot 7$ & 106 & $109 \cdot 0$ & 0.69 & 2286 & 1.6 & -511.5 \\
\hline 276 & $96 \cdot 2$ & 106 & $109 \cdot 0$ & 0.96 & 2003 & $2 \cdot 0$ & $489 \cdot 0$ \\
\hline 276 & $32 \cdot 4$ & 108 & $109 \cdot 0$ & $3 \cdot 15$ & 2173 & 1.6 & $451 \cdot 5$ \\
\hline 276 & $20 \cdot 5$ & 112 & $109 \cdot 0$ & 3.97 & 1671 & $2 \cdot 4$ & $439 \cdot 0$ \\
\hline 276 & 13.7 & 104 & $109 \cdot 0$ & 4.66 & 1412 & $1 \cdot 3$ & 416.5 \\
\hline 244 & $90 \cdot 4$ & 92 & $102 \cdot 6$ & $1 \cdot 12$ & 2531 & 0.66 & 462.5 \\
\hline 244 & $60 \cdot 2$ & 92 & 102,6 & 1.51 & 2273 & 0.52 & $444 \cdot 0$ \\
\hline
\end{tabular}

When experiments done with the diluted salt are taken into account a clearly different behaviour is also observed in the overpotential decay. The decay curves in those cases still follow (2), as shown in Fig. 8, but the linear region of lower slope located at higher overvoltages in the logarithmic plot disappears. The only linear portion observed extends now from 2 ms upwards with an average slope of 2.3 $(R T / F)$.

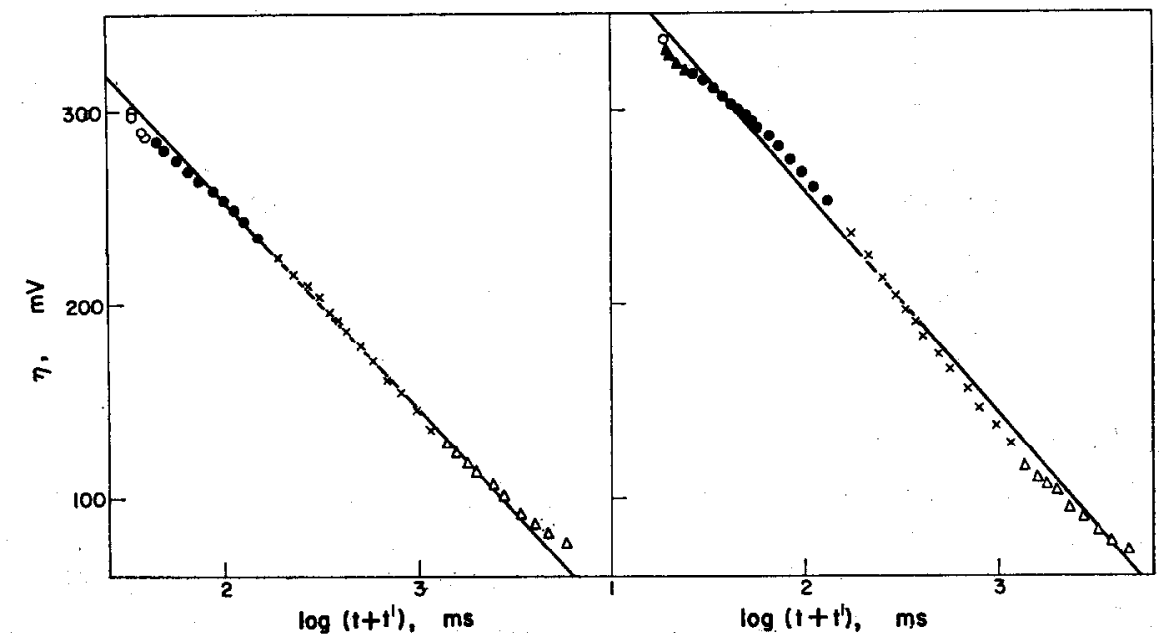

Fig. 8. Decay of overpotential for $1.08 \mathrm{M} \mathrm{NaNO}$, dissolved in the eutectic

$$
\begin{array}{ll}
\multicolumn{2}{c}{\mathrm{KNO}_{2}-\mathrm{NaNO}_{3}, \text { according to (2). }} \\
315^{\circ} \mathrm{C} & 315^{\circ} \mathrm{C} \\
29.6 \mathrm{~mA} / \mathrm{cm}^{2} & 50.6 \mathrm{~mA} / \mathrm{cm}^{2}
\end{array}
$$

Another important observation in the present case is that the initial part of the decay curve, seen in Fig. 9, is rather complicated, as it shows a dependence on the current density used in the previous electrolysis. So, for $\log t(\mathrm{~ms})=-1$, at $i=29.6 \mathrm{~mA} / \mathrm{cm}^{2}, \eta=300 \mathrm{mV}$, while at $i=50.6 \mathrm{~mA} / \mathrm{cm}^{2}, \eta=335 \mathrm{mV}$. It is interesting to note that the electrode capacitance calculated from $t^{\prime}$ is about ten 


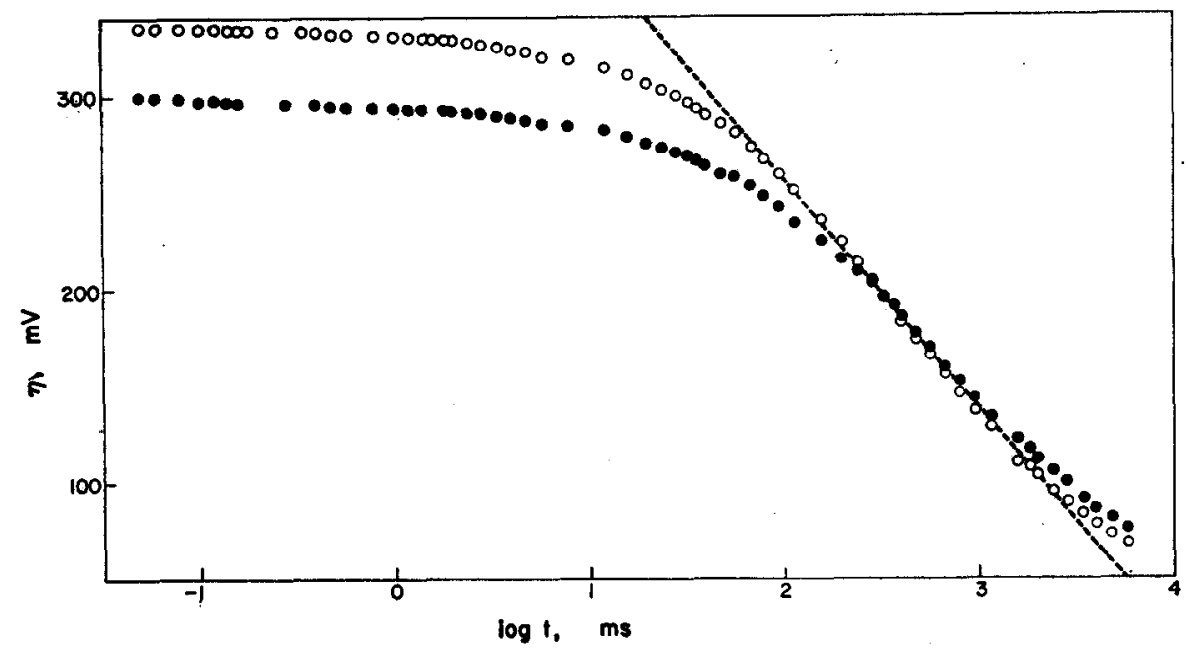

Fia. 9. Decay of overpotential for the diluted salt. Effect of current density. $1.08 \mathrm{M} \mathrm{NaNO}$, in $\mathrm{KNO}_{3}-\mathrm{NaNO}_{3} 315^{\circ} \mathrm{C}$.

$$
\begin{aligned}
& 0.6 \mathrm{~mA} / \mathrm{cm}^{2} \\
& 029.6 \mathrm{~mA} / \mathrm{cm}^{2}
\end{aligned}
$$

times greater for the diluted nitrites than for the pure salt. These results show that a concentration gradient of the reacting species interferes in the anodic process when the diluted salt is employed. This is a confirmation of previously obtained results and this effect becomes larger as the current density increases. Typical results obtained with the diluted salt are assembled in Table 4.

Table 4. Electrolyte: $1.08 \mathrm{M} \mathrm{NaNO}_{2}, 317^{\circ} \mathrm{C}$

\begin{tabular}{cccc}
\hline $\begin{array}{c}i \\
\mathrm{~mA} / \mathrm{cm}^{\mathrm{2}}\end{array}$ & $\begin{array}{c}\left(b_{\mathrm{d}}\right)_{1} \\
\mathrm{mV}\end{array}$ & $\begin{array}{c}t_{1}^{\prime} \\
\mathrm{ms}\end{array}$ & $\begin{array}{c}C \times 10^{-8} \\
\mu F / \mathrm{cm}^{2}\end{array}$ \\
\hline $50 \cdot 6$ & $116 \pm 10$ & 21.5 & $22 \pm 5$ \\
29.6 & 110 & $33 \cdot 9$ & 21 \\
18.5 & 106 & $50 \cdot 0$ & 20 \\
9.7 & 93 & 69.2 & 17 \\
\hline
\end{tabular}

\section{Build-up curves}

Build-up curves were obtained galvanostatically. They are shown in Fig. 10 for the systems containing pure molten nitrites. The initial slope of build-up curves was used to evaluate the electrode capacitance at the equilibrium potential. Figures reported in Table 5 indicate a low electrode differential capacitance at the equilibrium potential, the effect of roughness of the working electrode being probably negligible.

When diluted salt is used, however, the electrode capacitance at the initial potential is appreciably increased, as shown in Table 6.

\section{Residual cell}

About 150 s after the interruption of electrolysis, a residual reversible cell was left in the electrolysis cell, comprising the working electrode and the silver/silver-ion reference electrode. This reversible cell can be interpreted in terms of a nitrite reversible electrode. The existence of the latter was later confirmed and was studied 


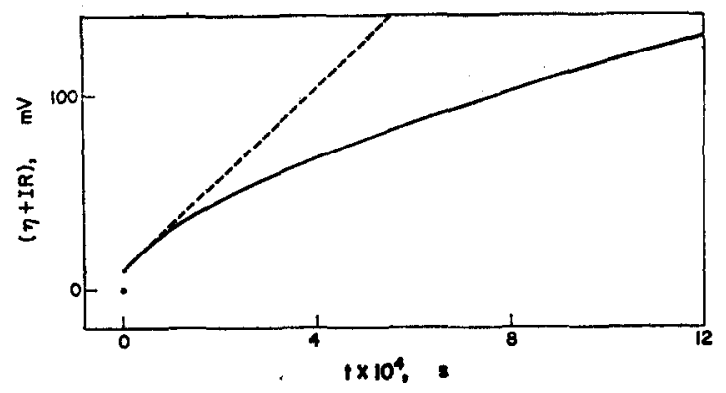

FIG. 10. Oscillographic trace of a build-up curve.

$$
\begin{aligned}
& 291^{\circ} \mathrm{C} \\
& 8 \mathrm{~mA} / \mathrm{cm}^{2} \\
& \mathrm{KNO}_{2}-\mathrm{NaNO}_{2}
\end{aligned}
$$

TABLE 5. Electrolyte: $\mathrm{NaNO}_{8}-\mathrm{KNO}_{2}$

\begin{tabular}{|c|c|}
\hline$\stackrel{i}{\mathrm{~mA} / \mathrm{cm}^{2}}$ & $\underset{\mu \mathrm{F} / \mathrm{cm}^{2}}{C}$ \\
\hline $\begin{array}{r}0.33 \\
2.26 \\
5.44 \\
11 \cdot 13\end{array}$ & $\begin{array}{c}54 \pm 10 \\
76 \\
80 \\
74\end{array}$ \\
\hline
\end{tabular}

\begin{tabular}{ccc}
\hline $\begin{array}{c}\text { Temp. } \\
{ }^{\circ} \mathrm{C}\end{array}$ & $\begin{array}{c}i \\
\mathrm{~mA} / \mathrm{cm}^{2}\end{array}$ & $\begin{array}{c}C \\
\mu \mathrm{F} / \mathrm{cm}^{2}\end{array}$ \\
\hline 291 & $246 \cdot 8$ & $49 \pm 10$ \\
& $8 \cdot 0$ & 35 \\
& $21 \cdot 6$ & 32 \\
& $19 \cdot 3$ & 31 \\
303 & $6 \cdot 3$ & 26 \\
& $17 \cdot 1$ & 15 \\
& $8 \cdot 5$ & 17 \\
& $39 \cdot 9$ & 17 \\
\hline
\end{tabular}

TABle 6. Electrolyte: $1.08 \mathrm{M} \mathrm{NaNO}_{2}, 315^{\circ} \mathrm{C}$

in detail by means of the sodium nitrite chemical cell, as described in another publication. ${ }^{8}$

The equilibrium on the platinum electrode involves the participation of nitrite ion and nitrogen dioxide, the latter being the gaseous product yielded by the anodic reaction as revealed by infra-red analysis. When a symmetrical electrode system was used in the measurement, the potential of the residual cell was obviously nil.

\section{DISCUSSION}

It is evident that reaction $I$ is the overall reaction taking place on the platinum anode and that results obtained with molten nitrite, mixtures of nitrite or nitrite dissolved in a nitrate mixture are complementary.

When nitrite is diluted in the nitrate mixture at low concentration, a net interference of a convective-diffusion process certainly exists, becoming significant at highest 
current densities, as has been observed in a previous work with higher dilution of nitrite. ${ }^{3}$ Part of the current/voltage curve are then interpreted in terms of the Nernst equation for concentration polarization, $\eta_{c}$,

$$
\eta_{0}=\frac{2 \cdot 3 R T}{F} \log \frac{i-i_{\mathrm{NO}_{\mathrm{z}}}}{i_{\mathrm{NO}_{\mathrm{a}}-}-i}
$$

where $i_{\mathrm{NO}_{2}}$ and $i_{\mathrm{NO}_{2}-}$ are the limiting current densities for the oxidant and reductant, respectively.

For pure salt as well as for the solutions employed a Tafel relationship between the overvoltage and current density has been observed, showing a first slope approaching $2 \cdot 3(R T / F)$. At first sight it would appear reasonable to assign these results to (4), since the latter under certain conditions yields a Tafel type relationship between overvoltage and log (current density).

The following experimental facts indicate that the electrode reaction is an activated electrochemical process, at least for the pure salt and for the more concentrated mixtures : (i) the type of decay of the anodic overvoltage systematically observed (ii) the independence of the decay curves from the previous current flowing through the cell, particularly for pure nitrite (iii) the change of Tafel slope observed in potential/log $i$ curves for pure nitrite (iv) the large dependence of apparent exchange current density on temperature (v) the appreciable change of Tafel slope and apparent exchange current density when graphite anodes are employed. ${ }^{8}$

Consequently, to elaborate a satisfactory explanation of results, the kinetic parameters must be properly related to the properties of the electrode/electrolyte interphase, where the reaction actually occurs.

Both current/voltage and decay curves plotted according to (2) yield remarkably coincident values for the exchange current density and the Tafel slope, which approaches respectively the values $2 \cdot 3(R T / F)$ and $2 \cdot 3(R T / 2 F)$ at overpotentials lower or higher than $320 \pm 50 \mathrm{mV}$ at $T=270^{\circ} \mathrm{C}$. Hence the same electrode process determines the behaviour of the electrode in the steady and non-steady states.

It is in general difficult to explain a slope $2 \cdot 3(R T / F)$ if the reaction involves a single electron, as is likely to be the case for nitrite ion. That slope means that the product $z \beta=1$, where $z$ is the number of electrons entering the rate-determining step and $\beta$ is the symmetry factor. It might occur if the electrode reaction is kinetically controlled by the simultaneous discharge of two nitrite ions, involving the participation of two electrons, but this is very unlikely since it requires a dependence of the exchange current density on the square of the nitrite ion concentration, which is not observed.

The fact that the exchange current density related to the slope $2 \cdot 3(R T / F)$ is greater than the one corresponding to the slope $2 \cdot 3(R T / 2 F)$ suggests that a simple interpretation may be given by postulating a reaction scheme comprising at least two competing steps, so that alternative reaction paths are possible.

Before attempting a detailed analysis of the probable reaction paths it is worth while to consider the figures for the electrode capacitances at different potentials. From the Tables, (i) the differential capacitance resulting from the build-up curves at the reversible potential indicates a value of the order expected for Helmholtz double layer (ii) capacitances calculated from the decay curves yield two values, corresponding to the two slopes already mentioned; the extrapolation of the straight line of lower 
slope yields very low values for $C$ which moreover are very uncertain (iii) the differential capacitances under (i) are not appreciably changed by temperature, whereas the capacitances under (ii) decrease notably as temperature increases. These facts indicate the existence of pseudo-capacitance associated with the electrode reaction, which probably results from an accumulation of reaction intermediates at the electrode interphase.

As recently demonstrated, ${ }^{9,10}$ pseudo-capacitances either increase with, are independent of, or decrease with the electrode potential according to the electrocapillary curve and degree of surface coverage of the electrode.

In the present case, pseudo-capacitance increases with potential; at constant temperature, for a range of potential of $100 \mathrm{mV}$, they increase by a factor of about 2. This means that in most of the experiments we are concerned with the ascending branch on the electrocapillary curve and therefore the degree of surface coverage is $<0.5$.

To interpret the electrode process which produces nitrogen dioxide from nitrite ion, on a platinum electrode, a single adsorbed intermediate will be assumed. The following are possible steps:

$$
\begin{aligned}
\mathrm{NO}_{2}^{-}+\mathrm{Pt} & =\left(\mathrm{NO}_{2}\right) \mathrm{Pt}+\mathrm{e} \\
\left(\mathrm{NO}_{2}\right) \mathrm{Pt}= & \mathrm{NO}_{2}+\mathrm{Pt} \\
2\left(\mathrm{NO}_{2}\right) \mathrm{Pt}= & \mathrm{N}_{2} \mathrm{O}_{4}+2 \mathrm{Pt} \\
\downarrow \uparrow & \\
& 2 \mathrm{NO}_{2}
\end{aligned}
$$

IIa yields an intermediate on the metal whose fate is determined by IIb and IIC. The final product is, in practice, nitrogen dioxide at experimental temperatures; the dissociation of nitrogen dioxide into nitric oxide and oxygen need not be considered. ${ }^{11}$

In the above reaction scheme, any one of the three reactions may be rate-determining.

The simplest way to analyse the reaction path is by considering each reaction in turn as the r.d.s. and the preceding steps as fast equilibrium processes, so that a quasi-steady state for the intermediates is assumed. On this basis, and assuming also a simple adsorption process of the Langmuir type, results comprised in Table 7 for the theoretical Tafel slopes, $b_{t}$, are obtained.

This simple treatment eliminates reaction IIa as rate-determining, but reactions IIb and IIc, lead to slopes coinciding with the slopes found at the different potential regions. Therefore it is reasonable to consider these reactions as alternative ratedetermining paths of the over-all process. Furthermore the electron-transfer process being fast, it is reasonable to find a reversible electrode involving nitrite ion, after current interruption.

However, the foregoing interpretation is based exclusively on a Langmuir isotherm for the intermediates, since the theoretical slopes correspond to the limiting case of a negligible degree of coverage. An alternative and perhaps better knowledge of the electrode reaction could be attained if the adsorption of intermediates are assumed to follow a Temkin isotherm. This is more satisfactory because the magnitude of the pseudo-capacitance at higher overvoltage indicates that the degree of surface coverage is appreciable and consequently a surface heterogeneity must be considered, leading in the simple picture to a linear variation of the apparent standard free energy of adsorption with coverage. ${ }^{12}$

The kinetic parameters obtained from the kinetic equations established for reaction scheme II, under Temkin conditions when a single adsorbed intermediate 
Table 7. Theoretical Tafel slopes, assuming LANGMUIR ISOTHERM AND $\beta=0.5, \eta \gg b_{\text {t }}$

\begin{tabular}{cc}
\hline Rate-determining step & $b_{t}$ \\
\hline IIa & $2 R T / F$ \\
IIb $\left\{\begin{array}{lc}X \rightarrow 0 \\
X \rightarrow \infty\end{array}\right.$ & $\infty T / F$ \\
IIc $\left\{\begin{array}{l}X \rightarrow 0 \\
X \rightarrow \infty\end{array}\right.$ & $R T / 2 F$ \\
\hline
\end{tabular}

is involved, are shown in Table 8. There the symmetry factors for reaction IIa and for the activation-controlled process are taken as 0.5 .

In this case reaction IIa is also eliminated as a rate-determining step, and the following two possibilities lead to a change of Tafel slope from a higher to a lower value as the reaction rate increases (i) reaction IIc is the r.d.s. involving initially an activated adsorption with a Tafel slope of $R T / F$ and turning into a non-activated adsorption process at higher potential, the Tafel slope changing to $R T / 2 F$ (ii) reaction IIb is initially the rate determining step as a non-activated adsorption process with a Tafel slope $R T / F$ and at higher overvoltages reaction IIc, as a non-activated adsorption process, becomes the rate-determining step, comprising a Tafel slope of $R T / 2 F$. The latter possibility offers to the electrode process alternative steps similar to those discussed assuming a Langmuir isotherm. Although both possibilities (i) and (ii) appear as possible reaction paths, the type of reaction entities and temperature involved in the present system points to possibility (ii) as the more likely.

In further discussing the change of slope, it is appropriate to analyse the rate equations resulting for the reaction when steps IIb and IIc become, respectively, rate-determining. Let $v_{i}$ and $k_{i}$ be the rate and rate constant for step $i, \Delta \phi$ the potential of the metal/molten-salt interphase, $X_{i}$ the degree of surface coverage by intermediates. The activity of nitrite ion is taken as unity for the pure nitrite melt, as well as the symmetry factor related to the non-activated adsorption process. We then get for reaction IIb

$$
v_{b}=\frac{k_{b} k_{a}}{k_{-a}} X_{i} \exp (\Delta \phi F \mid R T) \doteqdot k_{b} K_{a} \exp (\Delta \phi F \mid R T)
$$

and for reaction IIc

$$
v_{c}=k_{c}\left(\frac{k_{a}}{k_{-a}}\right)^{2} X_{i}^{2} \exp (2 \Delta \phi F / R T) \div k_{c} K_{a}^{2} \exp (2 \Delta \dot{\phi} F / R T) .
$$

Table 8. Theoretical Tafel slopes, assuming logarithmic

\begin{tabular}{|c|c|}
\hline Rate-determining step & $b_{i}$ \\
\hline $\begin{array}{l}\text { IIa }(X \rightarrow 0) \\
\text { IIb } \\
0<X<1 \text { \{activated adsorption }(\beta=1) \\
\text { IIc } \\
0<X<1 \text { non-activated adsorption } \\
\text { non-activated adsorption } \\
\text { activated adsorption }(\beta=1)\end{array}$ & $\begin{array}{l}2 R T / F \\
2 R T / F \\
R T / F \\
R T / 2 F \\
R T / F\end{array}$ \\
\hline
\end{tabular}
ISOTHERM AND $\beta=0.5, \eta \gg b_{t}$ 
These equations indicate that when $\Delta \phi$ (and eventually $\eta$ ) increases, $v_{b}$ increases more slowly than $v_{c}$, due to the different reaction order with respect to the concentration of the intermediate involved in $v_{b}$ and $v_{c}$, respectively. Furthermore, assuming the quasi-equilibrium for step $\mathrm{IIa}$, the concentration of the intermediate should increase linearly with the nitrite concentration in the melt. For the diluted systems it will thus not be possible to reach the region of the lower Tafel slope before interference by the convective-diffusion process.

The simple scheme, involving IIb and IIc as rate-determining steps in an alternative reaction path, yields therefore a reasonable explanation of the anodic electrode process, as far as the magnitude and transition of the Tafel slopes are concerned.

An interpretation of the experimental activation energies may be deduced from the data obtained with the symmetrical electrochemical system, considering the rate equations at $\eta=0$, and assuming that under those circumstances the degree of surface coverage is much less than unity and that the interphase structure behaves to first approximation as temperature-independent. The exchange current densities are respectively given by

and

$$
\left(i_{0}\right)_{b} \approx F k_{b} \frac{k_{a}}{k_{-a}} \approx\left(i_{0}\right)_{1}
$$

$$
\left(i_{0}\right)_{c} \approx 2 F k_{c}\left(\frac{k_{a}}{k_{-a}}\right)^{2} \approx\left(i_{0}\right)_{2} .
$$

With the pure nitrite melt, the corresponding activation energies for the electrode process are obtained when IIb and IIc are respectively the r.d.s.

and

$$
\Delta E_{1}=E_{b}+\left(E_{a}-E_{-a}\right) \approx\left(E_{1}\right)_{\exp }
$$

$$
\Delta E_{2}=E_{c}+2\left(E_{\alpha}-E_{-a}\right) \approx\left(E_{2}\right) \text { exp, }
$$

where $E_{i}$ is the activation energy for step $i$. Since step Ila is reversible, we can take $E_{a}-E_{-a} \approx \Delta H_{a}$, if $\Delta H_{a}$ is the enthalpy change at the working temperature associated to the equilibrium IIa. From the temperature coefficient of both $i_{0}$ 's a ratio of about 2 is obtained between $\Delta E_{2}$ and $\Delta E_{1}$, which indicates that $E_{b}$ and $E_{c}$ must be negligible as compared to the thermal effect observed. It also means that the energy of interaction between the intermediate and the electrode surface is of the same order of magnitude and probably negligible, as was supposed in the previous discussion.

Finally, it should be mentioned that the possibility of reaction paths with several adsorbed intermediates has been considered, but the probability of their occurrence is very small. This fact also emerges from a study of the anodic reaction on pure graphite electrodes, which will be shortly published.

Acknowledgement-This work was in part financially supported by the Consejo Nacional de Investigaciones Cientificas y Técnicas of Argentina. A. J. C. thanks the Consejo for the fellowship granted.

\section{REFERENCES}

1. Yu. S. Lyalxxov, Zh. analit. Khim. 8, 38 (1953); Chem. Abstr. 47, 5273a (1953).

2. YU. S. Lyalnkov and R. M. Novix, Uchen. Zap. kischinevsk. gos. Univ. 27, 61 (1957); Chem. Abstr. 54, 22101d (1960).

3. H. S. Sworrord JR. and P. G. McCormick, Analyt. Chem. 37, 970 (1965). 
4. A. J. Calandra and A. J. ARvin, Electrochim. Acta 10, 474 (1965).

5. W. E. Triaca and A. J. ARviA, Electrochim. Acta 9, 1055 (1964); A. J. Arvfa, A. J, Calandra and W. E. TRIACA, Electrochim. Acta 9, 1417 (1964).

6. W. E. TriacA and A. J. ArviA, Electrochim. Acta 10, 409 (1965).

7. A. J. Arvía, A. J. Calandra and H. A. Videla, Electrochim. Acta 10, 33 (1965).

8. A. J. Calandra and A. J. Arvia, to be published.

9. B. E. Conway and P. L. Bourgault, Trans. Faraday Soc. 58, 593 (1962).

10. B. E. ConwaY and E. Gileadi, Trans. Faraday Soc. 58, 2493 (1962).

11. A. P. Altshuller, J. phys. Chem. 61, 251 (1957).

12. B. E. ConwaY, in Modern Aspects of Electrochemistry, No. 3, ed. J. O'M. Bockris and B. E. Conway, Chap. 5. Butterworths, London (1964); J. G. N. Thomas, Trans. Faraday Soc. 57, 1603 (1961). 